Юкіш Г.Я.

\title{
Аналіз медико-організаційних та інформаційних чинників успішності реабілітаційного процесу після травм опорно-рухового апарату
}

\author{
Івано-Франківський національний медичний університет МОЗ України, м. Івано-Франківськ, Україна
}

gyukish@ifnmu.edu.ua

\begin{abstract}
Юкиш Г.
Анализ медико-организационных и информационных факторов успешности реабилитационного процесса после травм опорно-двигательного аппарата

Ивано-Франковский национальный медицинский университет, г. Ивано-Франковск, Украина
\end{abstract}

Yukish $\mathrm{H}$.

Analysis of medical, organizational, and informational factors of success of rehabilitation process after musculoskeletal injuries

Ivano-Frankivsk national medical university, Ivano-Frankivsk, Ukraine

\section{Вступ}

Інвалідність населення складає значну проблему сучасності не тільки для системи охорони здоров'я, а й для держави загалом, оскільки більшість людей з інвалідністю потребують реабілітаційних послуг, спрямованих на відновлення оптимального фізичного, інтелектуального, психічного і соціального рівня життедіяльності особи 3 метою сприяння їх інтеграції в суспільство $[4,7,16]$.

За даними ВОО3, кількість осіб 3 інвалідністю у світі складає більше 1 мільярда осіб (близько 15\%). 3 них - майже 200 мільйонів мають серйозні труднощі у функціонуванні. Причому, за прогнозами експертів, кількість осіб з інвалідністю у майбутньому буде тільки зростати $[2,7,11,15]$.

В Україні чисельність осіб як з вродженою, так і 3 набутою інвалідністю залишається відносно сталою, проте за рахунок зменшення чисельності населення зростає частка таких людей в популяції. За даними Центру перспективних соціальних досліджень Міністерства соціальної політики України та НАН України, на початку 2020 року зареєстровано 2,7 мільйона осіб, які мають статус людини 3 інвалідністю, що становить 6,4\% від загальної кількості населення, у порівнянні із 2011 роком, коли кількість таких осіб становила також 2,7 мільйона, але це складало 5,9\% [3]. Як бачимо, попри негативні тенденції, рівень інвалідності населення в Україні через складну процедуру експертизи i особливості законодавства про пенсійне страхування суттєво менший за відповідний європейський показник, який перевищує $10 \%[4]$.

Серед причин інвалідизації населення стабільно високе третє місце (після хвороб системи кровообігу та злоякісних захворювань) займає травматизм, який уражає переважно молоде працездатне населення, зазвичай вимагає довготривалого лікування та реабілітації, а отже складає значний соціально-економічний тягар для суспільства $[3,9,12,15]$.

Інвалідність - проблема багатогранна, залежить від рівня економічного, політичного, соціального та культурного розвитку держави i вимагає державного регулювання інтегрованих зусиль різних інституцій для забезпечення повноцінної реабілітації неповносправних осіб $[1,5,8]$.

В нашій державі прийнятий i функціонує Закон України «Про реабілітацію осіб з інвалідністю в Україні» (2005), де зазначено, що інвалідність це - міра втрати здоров'я у зв'язку із захворюванням, травмою (iіi наслідками) або вродженими вадами, що при взаємодії iз навколишнім середовищем може призводити до обмеження життєдіяльності особи, внаслідок чого держава зобов'язана створити умови для реалізації нею прав нарівні 3 іншими громадянами та забезпечити іiі соціальний захист [6].

Позитивні наміри нашої держави щодо цивілізованого вирішення проблеми інвалідності проявились і у ратифікації в грудні 2009 р. Верховною Радою України Конвенції про права осіб з інвалідністю, де викладені послідовні кроки, які повинні зробити держави для забезпечення прав людей з інвалідністю. Конвенція акцентує увагу на тому, що інвалідність живе у суспільстві, а не в особі і повинна розглядатися, як результат взаємодії між особою та його оточенням. А сама інвалідність виникає як результат бар'єрів, збудованих суспільством щодо людей 3 інвалідністю, наприклад, таких, як стигма та дискримінація, низька доступність послуг з охорони здоров'я та реабілітаційних послуг чи проблем доступності транспорту, приміщень та інформації [13].

У 2011 році ВОО3 та Світовим банком була підготована Всесвітня доповідь щодо інвалідності, над якою працювало більш ніж 380 експертів з різних країн світу, що дало змогу узагальнити основні перешкоди у 
суспільстві, які стають на заваді особам з інвалідністю. Серед них: неадекватні заходи політики і стандарти, нестача послуг, проблема з надання послуг, а саме - низьке кадрове забезпечення, недостатнє фінансування, відсутність доступності, неадекватні інформація і комунікація, відсутність консультування та включення в суспільне життя, відсутність даних і досвіду [16].

Ще в одному надзвичайно важливому міжнародному документі, ратифікованому в Україні (2017) - Міжнародній класифікації функціонування, обмеження життєдіяльності та здоров'я (МКФ) зазначено, що інвалідність - це «бар'єри середовища такою ж мірою, як це пов'язано зі станом здоров'я або порушеннями», а також рекомендовано замість терміну «інвалідність» застосовувати термін «обмеження життєдіяльності» труднощі, яких може зазнавати особа при здійсненні діяльності. За визначенням МКФ, бар'єри - це інституційні, ментальні, фізичні та інформаційні фактори в оточенні людини, які через їх відсутність або присутність обмежують функціонування та створюють обмеження життєдіяльності [14].

Слід зазначити, що попри ратифікацію усіх згаданих міжнародних документів та існування відповідного Закону, в Україні все ще не має цілісної інтегральної системи реабілітації осіб з інвалідністю, яка покривала б усі рівні надання необхідної допомоги. Про це було відзначено і у висновку місії ВООЗ, яка у 2015 році інспектувала наявний стан справ і констатувала, що більшість реабілітаційних закладів в Україні досі працює так само, як i за часів Радянського Союзу, послуги традиційно надаються переважно в курортному середовищі, створено та функціонує лише кілька сучасних реабілітаційних закладів, немає кадрів, які відповідали б світовим стандартам надання реабілітаційних послуг [9].

Тому, на сьогодні гостро стоїть питання формування сучасної системи реабілітації в державі, здатної задовольнити медичні та немедичні проблеми людей з інвалідністю.

Мета - виявити медико-організаційні та інформаційні чинники, які можуть мати потенційний вплив на успішність реабілітаційного процесу після травм опорно-рухового апарату і на задоволеність пацієнтів.

\section{Матеріали та методи}

Провели медико-соціальне дослідження репрезентативної вибірки 150 осіб з інвалідністю після травм опорно-рухового апарату за спеціально розробленою авторською програмою, яка включала питання стосовно демографічних, соціально-економічних, соціально-психологічних характеристик опитаних, а також їх поінформованості і ставлення до отриманих медичних та реабілітаційних послуг.

Збір даних проводився впродовж 2018 року на базі Івано-Франківського бюро медико-соціальної експертизи, яке була обране як наукова база дослідження. Опитування для об'єктивізації даних було анонімним (за бажанням пацієнта) i проводилось у момент чергового переосвідчення реабілітантів. Відбір обстежених проводився випадковим методом.

Склад опитаних за віком: до 30 років - 7,3\%,3039 років $-31,1 \%, 40-49$ років - 30,5\%, 50-59 років - 30,5\%, 60 і старші - 0,7\%; за статтю: чоловіки - 69,5\%, жінки 30,5\%; за місцем проживання: мешканці міст - 35,1\%, сіл $-64,9 \%$.

Розробка отриманого матеріалу проводилась шляхом формування баз даних на основі Microsoft Excel, де матеріали групувались за місцем проживання, статтю та віком.

Статистична обробка отриманого матеріалу проводилась шляхом розрахунку частоти поширення чинників на 100 опитаних та стандартної похибки $( \pm \mathrm{m})$ для відносних величин, а оцінка достовірності різниці даних в групах порівняння та перевірка нульової гіпотези здійснювалась шляхом розрахунку критерію відповідності хі-квадрат $\left(\chi^{2}\right)$ Пірсона.

Використано методи: епідеміологічний, соціологічний, медико-статистичний.

\section{Результати дослідження та їх обговорення}

Встановлено, що найчастіше під час переосвідчення, незалежно від віку, статі та місця проживання ( $>0,05)$, респондентам присвоювалась III група інвалідності $(75,5 \pm 3,5 \%)$, ще у чверті випадків $(22,5 \pm 3,4 \%)$ - II група та лише $2,0 \pm 1,1 \%$ - I група (рис. 1). Тобто, у майже $80 \%$ випадків причинами інвалідності є травми, які мають високий реабілітаційний потенціал, про що свідчать і терміни переосвідчення: приблизно $40 \% \quad(39,7 \pm 4,0 \%) \quad$ респондентів група інвалідності встановлювалась терміном на один рік і ще майже аналогічній частці $(43,7 \pm 4,0 \%)$ - на два роки; тільки $15,2 \pm 2,9 \%$ опитаних отримали інвалідність на три роки і в поодиноких випадках $(1,3 \pm 0,9 \%)$ - безстроково. Однак, дані офіційної статистики свідчать, що частка осіб із стійкою втратою працездатності, які під час переоглядів медикосоціальними комісіями повторно визнавалися особами 3 інвалідністю, протягом останніх десятиріч коливалась у межах 91,3-99,2\%, що вказує на неефективність застосовуваних реабілітаційних заходів [10].

Виявлено, що респонденти найчастіше втрачали працездатність на тривалий час внаслідок переломів кісток кінцівок - нижніх $(40,7 \pm 4,0 \%)$ та верхніх $(18,7 \pm 3,2 \%)$. П'ята частина опитаних $(20,0 \pm 3,3 \%)$ отримали статус особи з інвалідністю після травми хребта, ще $11,3 \pm 2,6 \%$ - внаслідок травматичної ампутації ділянок тіла. Значно рідше причиною були множинні переломи $(6,0 \pm 1,9 \%)$ та термічні чи хімічні опіки $(3,3 \pm 1,5 \%)$.

Опитані особи 3 інвалідністю характеризувались доволі високим рівнем освіти. У кожного п'ятого була вища $(21,9 \pm 3,4 \%)$, а в кожного другого - середня спеціальна $(48,3 \pm 4,1 \%)$ освіта. Менше третини респондентів $(27,8 \pm 3,6 \%)$ мали середню загальну освіту i лише $2,0 \pm 1,1 \%$ (усі 3 сільської місцевості) - нижче середньої. Це дає впевненість, що отримані під час опитування відповіді - адекватні. 
За результатами дослідження з'ясовано, що тільки половина респондентів $(47,0 \pm 4,1 \%)$ повністю впевнені у своїх знаннях щодо реабілітації, ще така ж частка
$(48,3 \pm 4,1 \%)$ вважали, що орієнтуються частково і незначний відсоток $(4,6 \pm 1,7 \%)$ зізналися, що зовсім не розуміють суті та мети реабілітаційного процесу.

III група; $75 \%$

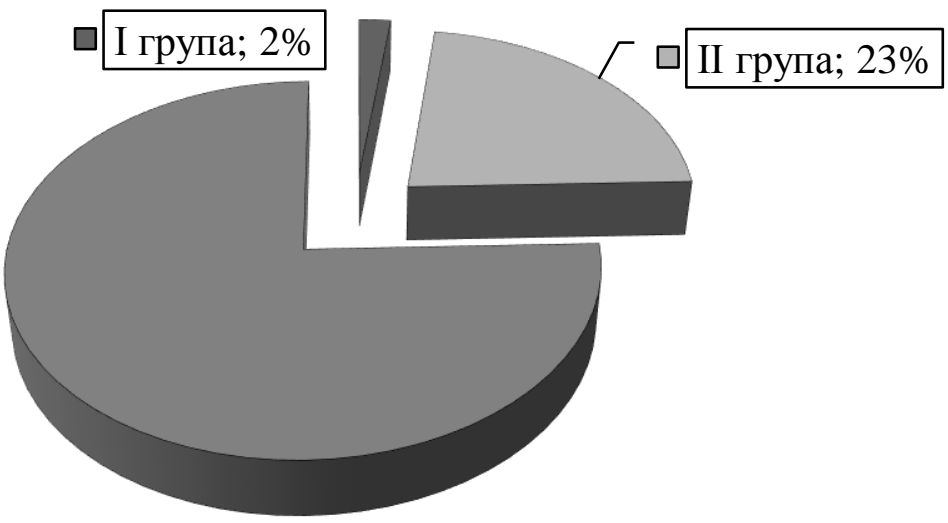

Рис. 1. Структура респондентів за групами інвалідності

Подальше опитування виявило співпадіння результатів самооцінки рівня поінформованості осіб 3 інвалідністю із об'єктивними даними. Респондентам було запропоновано вказати, що на їхню думку є основним завданням реабілітаційного процесу. Більше половини опитаних $(52,0 \pm 4,1 \%)$ обрали правильну відповідь відновлення втрачених функцій, решта були переконані, що максимально можливим результатом реабілітації $\epsilon$ пристосування до повсякденного життя $(32,7 \pm 3,8 \%)$ або ж

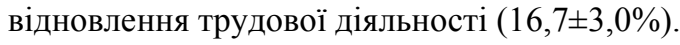

Встановлено, що повністю задоволеними результатами власної реабілітації були тільки $27,8 \pm 3,6 \%$ опитаних. Решта, в основній масі висловлювали часткову задоволеність $(61,6 \pm 4,0 \%)$, а кожен десятий респондент $(10,6 \pm 2,5 \%)$ відмітив, що зовсім не задоволений результатами проведеної реабілітації (рис. 2). При цьому виявлено, що чоловіки схильні позитивніше оцінювати проведений реабілітаційний процес, аніж жінки повністю задоволених серед них було удвічі більше, ніж серед жінок $(32,4 \pm 4,6 \%$ проти $17,4 \pm 5,6 \%, \mathrm{p}<0,05)$, а основними причинами незадоволення називались відсутність позитивної динаміки (62,5\%) та умов для реабілітації $(25,0 \%)$.

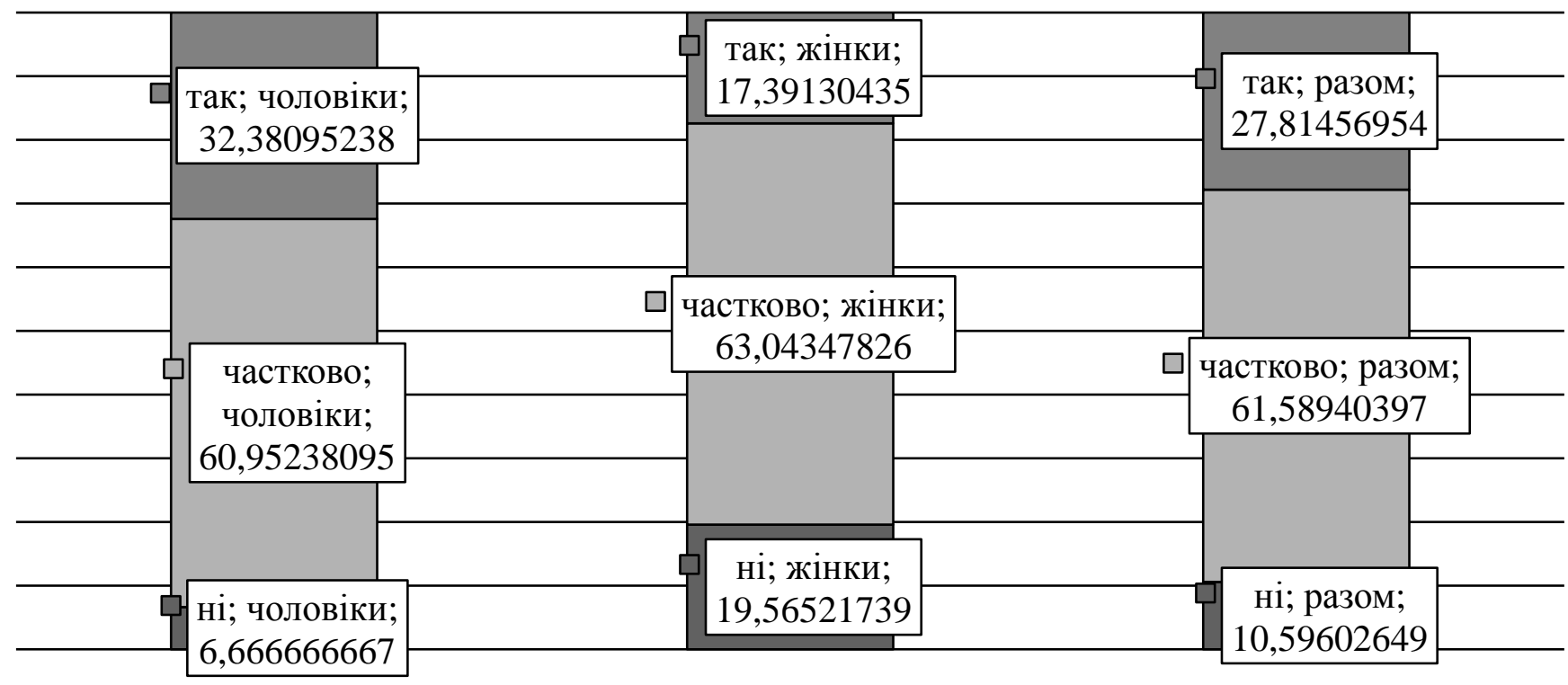

Рис. 2. Розподіл опитаних осіб з інвалідністю внаслідок травм опорно-рухового апарату за рівнем задоволеності результатами реабілітації в залежності від статі, \%

Четверта частина проанкетованих $(24,7 \pm 3,5 \%)$ поскаржилась, що їм зовсім не вдалося виконати необхідний перелік заходів, зазначених в їх індивідуальній програмі реабілітації (ІПР), розробленій при встановленні/ переосвідченні інвалідності медико-соціальною експертною комісією (МСЕК). Більшості респондентів 
$(68,0 \pm 3,8 \%)$ це вдалось лише частково і тільки $7,3 \pm 2,1 \%$ опитаних відзначили, що змогли в повному обсязі виконати всі рекомендації щодо реабілітаційного процесу (рис. 3).

Повнота виконання IПР не залежала від статі та віку респондентів ( $>0,05)$, проте суттєво відрізнялась у міських та сільських мешканців. Жителям міст в цілому краще вдалося дотримуватися індивідуальної програми реабілітації, аніж сільським мешканцям $(\mathrm{p}<0,01)$. Так, майже кожен п'ятий опитаний, що проживав у місті $(17,0 \pm 5,2 \%)$, підтвердив, що виконав всі рекомендовані МСЕК заходи, тоді як серед сільського населення таких поодинокі випадки $(2,1 \pm 1,4 \%)$. Разом 3 тим, питома вага жителів сіл, які зізналися, що їм зовсім не вдалося дотримуватися рекомендованих заходів, удвічі перевищує

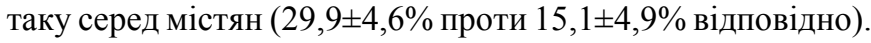

Це в черговий раз доводить, що повнота виконання ІПР залежить від доступності реабілітаційних заходів.

Ще одне підтвердження цього - половина проанкетованих $(50,0 \pm 4,3 \%)$, головним чином за рахунок чоловіків $(58,2 \pm 5,0 \%$ проти $30,0 \pm 7,2 \%$ серед жінок, $\mathrm{p}<0,01)$ вважала, що саме низький рівень матеріального благополуччя та нестача коштів стали основними причинами, які завадили виконанню заходів індивідуальної програми реабілітації.

Однак, третина $(31,9 \pm 4,0 \%)$ опитаних відповіли, що не були поінформовані про важливість дотримання IПР та не знали, куди звертатися. Тобто, під час чергового переосвідчення лікарями-експертами та лікаремреабілітологом МСЕК не був наданий весь обсяг необхідної інформації та не був розроблений маршрут пацієнта в кожному індивідуальному випадку.

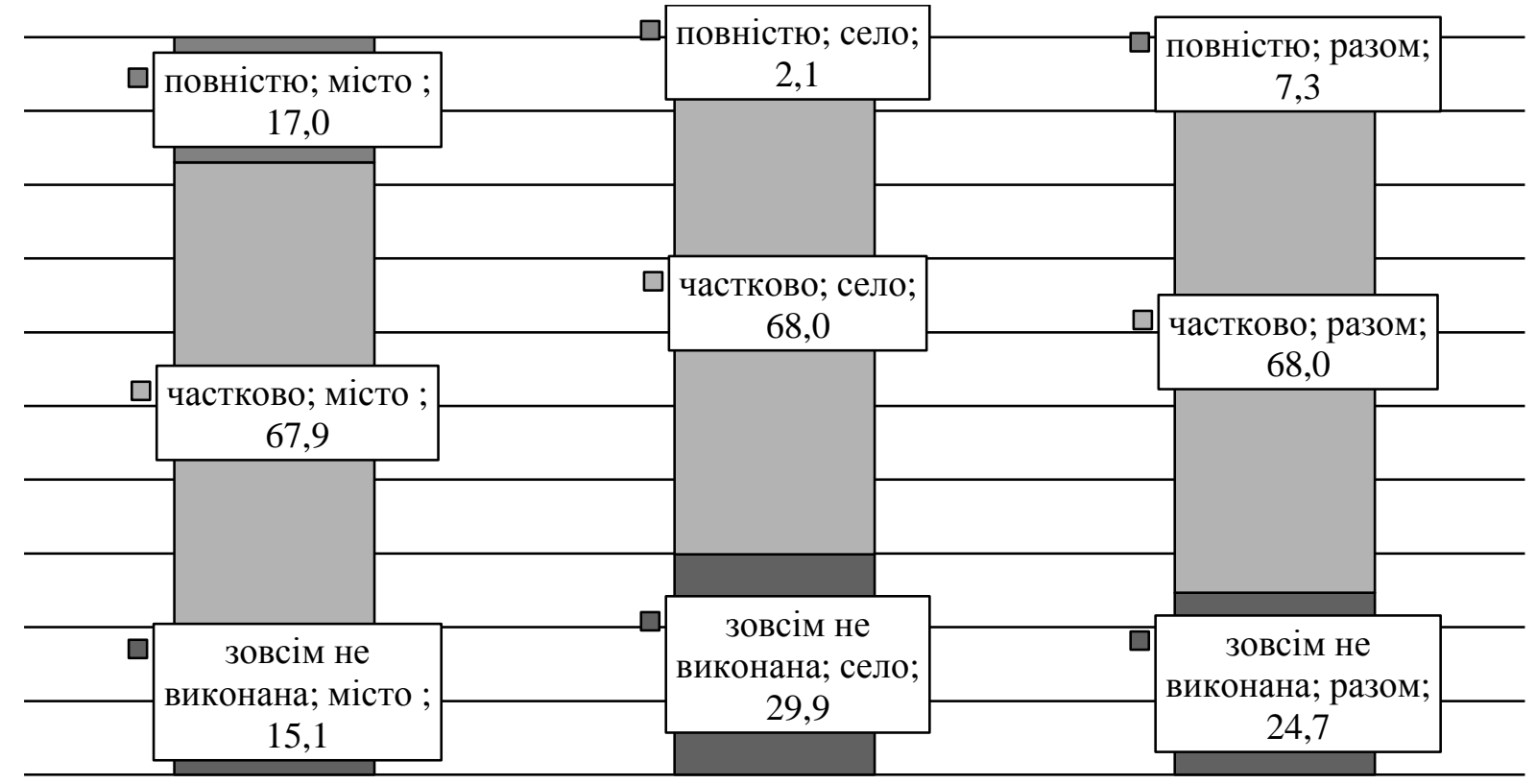

Рис. 3. Розподіл опитаних осіб з інвалідністю внаслідок травм опорно-рухового апарату за повнотою виконання індивідуальної програми реабілітації в залежності від місця проживання, \%

Очевидно, що на повноту виконання ІПР вплинуло й те, що лише половина респондентів $(56,3 \pm 4,0 \%)$ були охоплені диспансерним спостереженням 3 боку лікарятравматолога 3 приводу причини стійкої втрати працездатності. Решта - не знали $(35,1 \pm 3,3 \%)$, що це таке, i ще $8,6 \pm 2,3 \%$ - визнали, що не стояли на диспансерному обліку. При цьому, кожен п'ятий опитаний $(20,5 \pm 3,3 \%)$ взагалі не був поінформований, що після встановлення/ продовження групи інвалідності лікарями МСЕК йому необхідно звернутися до лікаря-травматолога амбулаторного закладу для подальшого диспансерного спостереження і контролю виконання його індивідуальної програми реабілітації.

Дисонансом на цьому тлі виглядають ствердні відповіді більшості $(74,8 \pm 3,5 \%)$ реабілітантів на питання щодо регулярності відвідування ними лікарятравматолога згідно з рекомендаціями лікарів МСЕК. Лише кожен четвертий респондент $(23,8 \pm 3,5 \%)$ зізнався, що здійснює нерегулярні візити (тільки по мірі потреби), i одиниці $(1,3 \pm 0,9 \%)$ - що за останній рік жодного разу не були на прийомі в профільного спеціаліста. На наш погляд, ці дані підтверджують недоліки комунікацій лікарів із особами з інвалідністю.

Безумовно, характер травми, яка стала причиною встановлення групи інвалідності, вплинув на вибір методів лікування на кожному з етапів.

Виявлено, що одразу після отримання травми для більшості пацієнтів, незалежно від віку, статі та місця проживання, методом вибору було оперативне втручання $(80,0 \pm 3,3 \%)$, що в черговий раз засвідчує соціальноекономічний тягар інвалідизуючого травматизму (таблиця). Кожному четвертому $(25,3 \pm 3,6 \%)$ накладалась гіпсова пов'язка і значно рідше застосовувалось скелетне витягування $(9,3 \pm 2,4 \%)$, яке, як правило передує оперативному втручанню. 
Слід зазначити, що не медикаментозні методи відновлювального лікування, у повній відповідності із принципом раннього початку реабілітаційного процесу, були застосовані до частини пацієнтів уже в гострому періоді травми i ставали домінуючими після його завершення та після встановлення групи інвалідності, тобто розробки ІПР. При цьому, найчастіше застосовувався лікувальний масаж $(60,3 \pm 4,5 \%$ після завершення гострого періоду і $62,4 \pm 4,5 \%$ після встановлення групи інвалідності), а також лікувальна фізкультура, частота призначення якої за вказаний термін зросла у 1,5 рази (3 $38,8 \pm 4,5 \%$ до $51,3 \pm 4,6 \%$ відповідно). Зросло й охоплення санаторнокурортним лікуванням, хоча його частота була не такою суттєвою (з 7,8 $2,5 \%$ до $19,7 \pm 3,7 \%$ ). Звертає на себе увагу досить значна частота застосування мало доказових методів фізіотерапії, таких як: електрофорез $(32,2 \pm 4,4 \%$ i $29,9 \pm 4,2 \%)$, магнітотерапія $(16,4 \pm 4,4 \%$ і $15,4 \pm 3,3 \%)$ та парафінотерапія $(15,5 \pm 3,4 \%$ і $14,5 \pm 3,3 \%)$.

Відомо, що реабілітаційні заходи після встановлення групи інвалідності, у т. ч. індивідуальна програма реабілітації, передбачають не лише надання медичної допомоги, а й соціальну складову. Проте, кожен другий респондент $(52,3 \pm 4,1 \%)$ відзначив, що взагалі не поінформований, який соціальний пакет послуг передбачений за законом при інвалідності. Ще майже $40 \%(39,7 \pm 4,0 \%)$ мали часткову інформацію і повністю ознайомленими 3 цього питання були лише $7,9 \pm 2,2 \%$ опитаних.

Таблиця. Частота застосування різних методів лікування на різних етапах реабілітації осіб з інвалідністю після травм опорно-рухового апарату

\begin{tabular}{|l|c|c|c|}
\hline \multicolumn{1}{|c|}{ Метод лікування } & $\begin{array}{c}\text { Відразу після } \\
\text { травми, \% }\end{array}$ & $\begin{array}{c}\text { Після гострого } \\
\text { періоду травми, \% }\end{array}$ & $\begin{array}{c}\text { Після встановлення } \\
\text { групи інвалідності, \% }\end{array}$ \\
\hline Оперативне втручання & $80,0 \pm 3,3$ & $6,0 \pm 2,2$ & $1,7 \pm 1,2$ \\
\hline Гіпсова пов'язка & $25,3 \pm 3,6$ & $7,8 \pm 2,5$ & 0,0 \\
\hline Скелетне витягування & $9,3 \pm 2,4$ & $0,9 \pm 0,9$ & 0,0 \\
\hline Лікувальний масаж & $13,3 \pm 2,8$ & $60,3 \pm 4,5$ & $62,4 \pm 4,5$ \\
\hline Лікувальна фізкультура & $9,3 \pm 2,4$ & $38,8 \pm 4,5$ & $51,3 \pm 4,6$ \\
\hline Електрофорез & $6,7 \pm 2,0$ & $32,8 \pm 4,4$ & $29,9 \pm 4,2$ \\
\hline Магнітотерапія & $2,7 \pm 1,3$ & $16,4 \pm 3,4$ & $15,4 \pm 3,3$ \\
\hline Бальнеотерапія & $0,7 \pm 0,7$ & $7,8 \pm 2,5$ & $6,0 \pm 2,2$ \\
\hline Лазеротерапія & $0,7 \pm 0,7$ & $3,4 \pm 1,7$ & $5,1 \pm 2,0$ \\
\hline Парафінотерапія & $0,7 \pm 0,7$ & $15,5 \pm 3,4$ & $14,5 \pm 3,3$ \\
\hline Водолікування & $1,3 \pm 0,9$ & $6,0 \pm 2,2$ & $6,8 \pm 2,3$ \\
\hline Санаторно-курортне лікування & $0,7 \pm 0,7$ & $7,8 \pm 2,5$ & $19,7 \pm 3,7$ \\
\hline Інше & $5,3 \pm 1,8$ & $12,9 \pm 3,1$ & $9,4 \pm 2,7$ \\
\hline
\end{tabular}

Можливо на низьку поінформованість щодо належних при інвалідності соціальних послугах вплинуло те, що трохи менше половини проанкетованих $(43,0 \pm 4,0 \%)$ відмітили, що не потребують ніяких спеціальних засобів для реабілітації, а третина $(32,5 \pm 3,8 \%)$ просто не звертались за їх отриманням, хоча мають потребу.

Разом 3 тим, 3 тих 24,5 $\pm 3,5 \%$, які мають потребу i зверталися для отримання спеціальних засобів реабілітації, отримали їх в повному обсязі лише $37,8 \pm 8,0 \%$, а решта - або не отримали їх зовсім $(24,3 \pm 7,1 \%)$, або тільки частково $(40,5 \pm 8,1 \%)$.

\section{Перспективи подальших досліджень} полягатимуть у розробці науково обгрунтованої моделі удосконалення системи реабілітації осіб з інвалідністю після травм опорно-рухового апарату.

\section{Висновки}

Встановлено, що на тлі високого реабілітаційного потенціалу осіб 3 інвалідністю після травм опорнорухового апарату $(75,5 \pm 3,5 \%$ мали III групу інвалідності, у $83,4 \pm 3,0 \%$ термін переосвідчення до 2 -х років, у $59,3 \pm 4,0 \%$ причиною інвалідності були переломи кінцівок), тільки третина $(27,8 \pm 3,6 \%)$ опитаних повністю задоволені проведеною їм реабілітацією.

3'ясовано, що причинами недостатньої повноти виконання індивідуальної програми реабілітації (у $24,7 \pm 3,5 \%$ не виконана зовсім, у $68,0 \pm 3,8 \%$ - частково) можуть бути: низька доступність реабілітаційних заходів - фінансова $(50,0 \pm 4,3 \%$ опитаних скаржились

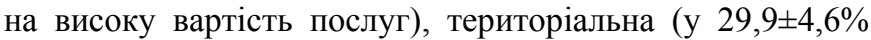
сільських мешканців програма реабілітації повністю не виконана) та функціональна (забезпеченість спеціальними засобами $-37,8 \pm 8,0 \%$ від потреби), а також недотримання медико-організаційних технологій (охоплені диспансерним спостереженням $56,3 \pm 4,0 \%$; нерегулярно чи зовсім не відвідують лікаря 3 контрольною метою $25,2 \pm 3,5 \%$, мало доказові методи немедикаментозного лікування призначались 15-30\% пацієнтів).

Показано, що попри досить високий рівень освіти (21,9\% з вищою та 48,3\% із середньою спеціальною), респонденти були недостатньо проінформовані щодо суті $(53,0 \pm 4,1 \%)$, мети $(48,0 \pm 4,1 \%)$ та важливості $(31,9 \pm 4,0 \%)$ реабілітаційного процесу, потреби у регулярних контрольних візитах до лікаря $(20,5 \pm 3,3 \%)$, належного 
при інвалідності пакету соціальних послуг $(52,3 \pm 4,1 \%$ взагалі і $39,7 \pm 4,0 \%$ - частково).
Існуюча вітчизняна система реабілітації осіб 3 інвалідністю після травм опорно-рухового апарату вимагає корекції та удосконалення.

\section{Література}

1. Віжунов ОВ. Історичні передумови формування поняття «особа 3 інвалідністю». Прикарпатський юридичний вісник. 2019;1(4). https://doi.org/10.32837/pyuv.v1i4(29).395.

2. Володіна ВС, Виноградов ОО, Гужва, ОІ. Інвалідність і питання доступності. В: Долинний ЮО, редактор. Педагогіка й сучасні аспекти фізичного виховання; 2019 кві. 17-19; Краматорськ, Україна. 2019. с. 238-46.

3. Державна служба статистики України. Соціальний захист населення України в 2019 році: стат. збірник. Київ: ДП "Держаналітінформ"; 2020. 116 с. Доступно 3: http://ukrstat.gov.ua/druk/publicat/kat_u/2020/zb/07/ zb_szn_2019.pdf.

4. Кабінет міністрів України. Концепція Загальнодержавної програми «Здоров’я 2020: український вимір». 2011. Розпорядження №1164-p. 2011 жовтень 31. Доступно 3: https://zakon.rada.gov.ua/laws/show/1164-2011-\%D1 $\% 80 \#$ Text.

5. Панасюк РВ. Еволюційний погляд на дефініцію «інвалідність». Актуальні проблеми психології: Збірник наукових праць Інституту психології імені Г.С. Костюка НАПН України. 2018; VII(45):240-52.

6. Про реабілітацію осіб з інвалідністю в Україні. Закон України від 6.10.2005 р. о 2961-IV. Доступно 3: https://zakon.rada.gov.ua/laws/show/2961-15.

7. Трегуб ПО, Арасланова ТР. Вплив інвалідності на соціально-економічні аспекти життя осіб з обмеженими можливостями. В: Огнєв ВА, Мельниченко ОА, Сокол КМ, Чухно ІА, редактори. Надбання сучасної епідеміології та біостатистики як запорука покращання громадського здоров’я в Україні; 2019 кві. 18; ХНМУ, Харків, Україна. 2019. c. $55-7$.

8. Трюхан ОА. Поняття та причини інвалідності як юридичного факту втрати працездатності. В: Ульянова ГО, редактор. Правове життя сучасної України; 2018 вер. 17; Одеса, Україна. Одеса: Гельветика; 2018. с. 192-5.

9. Чабарай Г. Труднощі реаблітації. Український тиждень; 2019. Доступно 3: https://tyzhden.ua/Society/225804.

10. Юкіш Г. Динаміка показників травматизму, інвалідності та смертності внаслідок нього в ІваноФранківській області за 2007-2016 рр. [тези доп.]. В: «Загальне охоплення послугами охорони здоров’я - для всіх і всюди»; 2018 кві. 5-6; Київ, Україна. 2018. с. 128-9.

11. Cieza A, Sabariego C, Bickenbach J, Chatterji S. Rethinking disability. BMC Med. 2018;16:14. Available from: doi: https://doi.org/10.1186/s12916-017-1002-6.

12. O'Donnell ML, Varker T, Holmes AC, Ellen S, Wade D, Creamer M et al. Disability after injury: the cumulative burden of physical and mental health. J Clin Psychiatry. 2013; 74(2):137-43. Available from: doi: 10.4088/JCP.12m08011

13. UN General Assembly, Convention on the Rights of Persons with Disabilities : resolution / Adopted by the General Assembly, 24 January 2007, A/RES/61/106, available from: https://www.refworld.org/docid/45f973632.html.

14. WHO. International classification of Functioning, Disability and Health. Geneva, 2011.

15. WHO. The global burden of disease: 2004 update. Geneva, 2008.

16. WHO. World report on disability. Geneva, 2011.

\section{References}

1. Vizhunov OV. Istorychni peredumovy formuvannia poniattia “osoba z invalidnistiu". Prykarpatski yurydychnyi visnyk [Internet]. 2019;1(4). Dostupno z: doi: https://doi.org/10.32837/pyuv.v1i4(29).395.

2. Volodina VS, Vynohradov OO, Huzhva OI. Invalidnist I pytannia dostupnosti. V: Dolynnyi YuO, redactor. Pedahohika I suchasni aspekty fizychnoho vykhovannia; 2019 kvi 17-19; Kramatorsk, Ukraina. 2019. s. 238-46.

3. Derzhavna sluzhba statystyky Ukrainy. Sotsialnyi zakhyst naselennia Ukrainy v 2019 rotsi: stat. zbirnyk. Kyiv: DP “Derzhanalitinform"; 2020. Dostupno z: http://ukrstat.gov.ua/druk/publicat/kat_u/2020/zb/07/zb_szn_2019.pdf.

4. Kabinet Ministriv Ukrainy. Kontseptsiia Zahalnoderzhavnoi prohramy “Zdorovia 2020: ukrainskyi vymir”. 2011. Rozporiadzhennia №1164-p. 2011 zhovten 31. Dostupno z: https://zakon.rada.gov.ua/laws/show/1164-2011-\%D1\%80\#Text.

5. Panasiuk RV. Evoliutsiinyi pohliad na definitsiiu "invalidnist”. Aktualni problem psyholohii: Zbirnyk naukovukh prats Instytutu psykholohii imeni H. S. Kostiuka NAPN Ukrainy. 2018;VII(45):240-52.

6. Pro reabilitatsiiu osib z invalidnistiu v Ukraini. Zakon Ukrainy vid 06.10.2005 r. No 2961-IV. Dostupno z: https://zakon.rada.gov.ua/laws/show/2961-15.

7. Trehub PO, Araslanova TR. Vplyv invalidnosti na sotsialno-ekonomichni aspekty zhyttia osib z obmezhenymy mozhlyvostiamy. V: Ohniev VA, Melnychenko OA, Sokol KM, Chukhno IA, redaktory. Nadbannia suchasnoi epidemiolohii ta biostatystyky yak zaporuka pokrashchannia hromadskoho zdorovia v Ukraini; 2019 kvi. 18; KHNMU, Kharkiv, Ukraina. 2019. s. 55-7. 
8. Triukhan OA. Poniattia ta prychyny invalidnosti yak yurydychnoho faktu vtraty pratsezdatnosti. V: Ulianova HO, redactor. Pravove zhyttia suchasnoi Ukrainy; 2018 ver. 17; Odesa, Ukraina. Odesa: Helvetyka; 2018. s. 192-5.

9. Chabarai H. Trudnoshchi reabilitatsii. Ukrainskyi tyzhden; 2019. Dostupno z: https://tyzhden.ua/Society/225804.

10. Yukish H. Dynamika pokaznykiv travmatyzmy, invalidnosti ta smertnosti vnaslidok nioho v Ivano-Frankivski oblasti za 2007-2016 rr. [tezy dop.]. V: "Zahalne ohoplennia posluhamy okhorony zdorovia - dlia vsikh I vsiudy"; 2018 kvi. 5-6; Kyiv, Ukraina. 2018. s. 128-9.

11. Cieza A, Sabariego C, Bickenbach J, Chatterji S. Rethinking disability. BMC Med. 2018;16:14. Available from: doi: https://doi.org/10.1186/s12916-017-1002-6.

12. O’Donnell ML, Varker T, Holmes AC, Ellen S, Wade D, Creamer M et al. Disability after injury: the cumulative burden of physical and mental health. J Clin Psychiatry. 2013; 74(2):137-43. Available from: doi: 10.4088/JCP.12m08011.

13. UN General Assembly, Convention on the Rights of Persons with Disabilities : resolution / Adopted by the General Assembly, 24 January 2007, A/RES/61/106, available from: https://www.refworld.org/docid/45f973632.html.

14. WHO. International classification of Functioning, Disability and Health. Geneva, 2011.

15. WHO. The global burden of disease: 2004 update. Geneva, 2008.

16. WHO. World report on disability. Geneva, 2011.

Дата надходження рукопису до редакції: 16.06 .2020 р.

Мета. Виявити медико-організаційні та інформаційні чинники, які можуть мати потенц
реабілітаційного процесу після травм опорно-рухового апарату і на задоволеність пацієнтів.

Матеріали та методи. Провели опитування репрезентативної вибірки 150 осіб з інвалідністю після травм опорно-рухового апарату, мешканців Івано-Франківської області.

Результати. Встановлено, що на тлі високого реабілітаційного потенціалу осіб з інвалідністю після травм

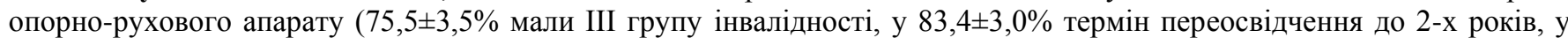
$59,3 \pm 4,0 \%$ причиною інвалідності були переломи кінцівок), тільки третина $(27,8 \pm 3,6 \%)$ опитаних повністю задоволені проведеною їм реабілітацією.

3'ясовано, що причинами недостатньої повноти виконання індивідуальної програми реабілітації (у $24,7 \pm 3,5 \%$ не виконана зовсім, у $68,0 \pm 3,8 \%$ - частково) можуть бути: низька доступність реабілітаційних заходів - фінансова

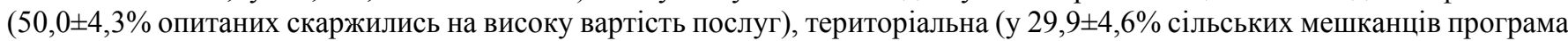
реабілітації повністю не виконана) та функціональна (забезпеченість спеціальними засобами - 37,8 $\pm 8,0 \%$ від потреби), а також недотримання медико-організаційних технологій (охоплені диспансерним спостереженням 56,3 $44,0 \%$; нерегулярно чи зовсім не відвідують лікаря з контрольною метою 25,2 $\pm 3,5 \%$, мало доказові методи немедикаментозного лікування призначались $15-30 \%$ пацієнтів).

Показано, що попри досить високий рівень освіти (21,9\% 3 вищою та 48,3\% із середньою спеціальною), респонденти були недостатньо проінформовані щодо суті $(53,0 \pm 4,1 \%)$, мети $(48,0 \pm 4,1 \%)$ та важливості $(31,9 \pm 4,0 \%)$ реабілітаційного процесу, потреби у регулярних контрольних візитах до лікаря $(20,5 \pm 3,3 \%)$, належного при інвалідності пакету соціальних послуг (52,3 $\pm 4,1 \%$ взагалі і $39,7 \pm 4,0 \%$ - частково).

Висновки. Існуюча вітчизняна система реабілітації осіб з інвалідністю після травм опорно-рухового апарату вимагає корекції та удосконалення. чинники

Ключові слова: організація охорони здоров’я, інвалідність, реабілітація, медико-організаційні та інформаційні

Цель. Выявить медико-организационные и информационные факторы, которые могут иметь потенциальное влияние на успешность реабилитационного процесса после травм опорно-двигательного аппарата и на удовлетворенность пациентов.

Материалы и методы. Провели опрос репрезентативной выборки 150 человек с инвалидностью после травм опорно-двигательного аппарата, жителей Ивано-Франковской области.

Результаты. Установлено, что на фоне высокого реабилитационного потенциала лиц с инвалидностью после травм опорно-двигательного аппарата $(75,5 \pm 3,5 \%$ имели III группу инвалидности, у $83,4 \pm 3,0 \%$ строк переосвидетельствования до 2-х лет, у 59,3 4 4,0\% причиной инвалидности были переломы конечностей), только треть $(27,8 \pm 3,6 \%)$ опрошенных полностью удовлетворены результатами реабилитации.

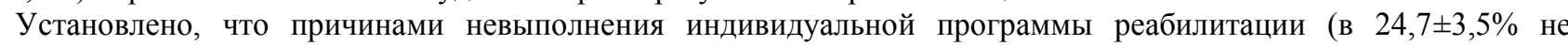
выполнено совсем, в $68,0 \pm 3,8 \%$ - частично) могут быть: низкая доступность реабилитационных мероприятий финансовая (50,0土4,3\% опрошенных жаловались на высокую стоимость услуг), территориальная (у $29,9 \pm 4,6 \%$ сельских жителей программа реабилитации полностью не выполнена) и функциональная (обеспеченность специальными средствами - 37,8 $\pm 8,0 \%$ от потребности), а также несоблюдение медико-организационных технологий (охвачены диспансерным наблюдением 56,3 $\pm 4,0 \%$; нерегулярно или совсем не посещают врача с контрольной целью $25,2 \pm 3,5 \%$, мало доказательные методы немедикаментозного лечения назначались 15-30\% пациентов). 
Показано, что, несмотря на достаточно высокий уровень образования $(21,9 \%$ с высшим и 48,3\% со средним

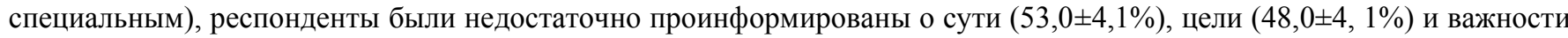
$(31,9 \pm 4,0 \%)$ реабилитационного процесса, потребности в регулярных контрольных визитах к врачу (20,5 $\pm 3,3 \%)$,

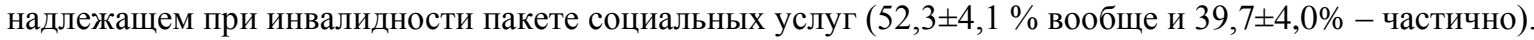

Выводы. Существующая отечественная система реабилитации лиц с инвалидностью после травм опорнодвигательного аппарата требует коррекции и усовершенствования.

Ключевые слова: организация здравоохранения, инвалидность, реабилитация, медико-организационные и информационные факторы.

Purpose. To identify medical, organizational and informational factors that may have a potential impact on the success of rehabilitation process after injuries of the musculoskeletal system and on patient satisfaction.

Materials and methods. A survey of a representative sample of 150 people with disabilities after injuries of the musculoskeletal system, residents of Ivano-Frankivsk region.

Results. It was found that against the background of high rehabilitation capability of persons with disabilities after musculoskeletal injuries $(75.5 \pm 3.5 \%$ had group III disability, in $83.4 \pm 3.0 \%$ term of re-examination up to two years, in $59.3 \pm 4.0 \%$ the cause of disability were limb fractures), only a third $(27.8 \pm 3.6 \%)$ of respondents fully satisfied with rehabilitation.

It was found that the reasons for the lack of completeness of the individual rehabilitation program (in $24.7 \pm 3.5 \%$ not implemented at all, in $68.0 \pm 3.8 \%$ - partially) may be: low access to the rehabilitation services - financial $(50.0 \pm 4.3 \%$ of respondents complained about the high cost of services), territorial $(29.9 \pm 4.6 \%$ of rural residents did not fully implement the rehabilitation program) and functional (access to special tools $-37.8 \pm 8.0 \%$ from needed), as well as non-compliance with medical and organizational technologies (covered by follow-up care $56.3 \pm 4.0 \%$, irregularly or not at all visit a doctor for control purposes $25.2 \pm 3.5 \%$, low evidence-based methods of non-drug treatment were prescribed to $15-30 \%$ of patients).

It is shown that despite a fairly high level of education $(21.9 \%$ with university and $48.3 \%$ with college education), respondents were insufficiently informed about the essence $(53.0 \pm 4.1 \%)$, purpose $(48.0 \pm 4,1 \%)$ and the importance $(31.9 \pm 4.0 \%)$ of the rehabilitation process, the need for regular follow-up visits to the doctor $(20.5 \pm 3.3 \%)$, the package of social services due to the disability $(52.3 \pm 4.1 \%$ at all and $39.7 \pm 4.0 \%$ - partly).

Conclusions. The existing domestic system of rehabilitation of persons with disabilities after musculoskeletal injuries requires correction and improvement.

Key words: health care organization, disability, rehabilitation, medical-organizational and informational factors.

\section{Відомості про автора}

Юкіш Галина Ярославівна - асистентка кафедри соціальної медицини та громадського здоров’я Івано-Франківського національного медичного університету МО3 України. +380 (95) 555-35-83, gyukish@ifnmu.edu.ua. 